\title{
Nephroprotective Effect of Aqueous Extract of Pimpinella anisum in Gentamicin Induced Nephrotoxicity in Wistar Rats
}

\author{
Nair Aiswarya ${ }^{1}$, Rao Rashmi R ${ }^{1 *}$, Shenoy Preethi J', Vinod Chandran², S Teerthanath ${ }^{3}$, Pai Sunil B ${ }^{1}$, KB Rakesh$^{1}$
}

\section{Nair Aiswarya', Rao Rashmi R*1, Shenoy Preethi $J^{1}$, Vinod Chandran'2, S Teerthanath ${ }^{3}$, Pai Sunil B' ${ }^{1}$, KB Rakesh ${ }^{1}$}

\section{'Department of Pharmacology, Kas-} turba Medical College, Mangalore, Manipal Academy of Higher Education, Manipal, Karnataka, INDIA.

2Department of Biochemistry, Kasturba Medical College, Mangalore, Manipal Academy of Higher Education, Manipal, Karnataka, INDIA.

${ }^{3}$ Department of Pathology, KS Hegde Medical Academy, Nitte University, Deralakatte, Mangalore, Karnataka, INDIA.

\section{Correspondence}

\section{Rashmi R Rao}

Assistant Professor, Department of Pharmacology, Kasturba Medical College, Mangalore, Manipal Academy of Higher Education, Manipal, Karnataka, INDIA.

Phone No: +91-8971401840

E mail Id: rashmi.rao@manipal.edu

\section{History}

- Submission Date: 30-07-2017;

- Review completed: 11-09-2017;

- Accepted Date: 20-11-2017

\section{DOI : 10.5530/pj.2018.3.66}

Article Available online

http://www.phcogj.com/v10/i3

\section{Copyright}

(C) 2018 Phcog.Net. This is an openaccess article distributed under the terms of the Creative Commons Attribution 4.0 International license.

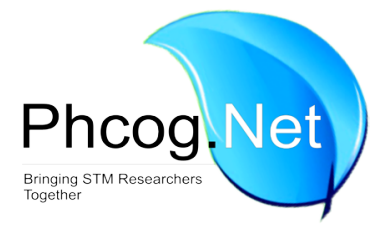

\begin{abstract}
Background: Pimpinella anisum known for its various medicinal properties is also a natural antioxidant and a free radical scavenger with no documented evidence as a nephroprotective agent. Objective: To evaluate the nephroprotective activity of aqueous extract of Pimpinella anisum seeds in a rodent model of gentamicin induced nephrotoxicity. Materials and Methods: Wistar albino rats of either sex, weighing 150-200 g was divided into 5 groups; normal saline, gentamicin $80 \mathrm{mg} / \mathrm{kg}$, intraperitoneally for 8 days, aqueous extract of Pimpinella anisum seeds at 1,2 , and $4 \mathrm{~g} / \mathrm{kg}$, per oral for 8 days, the test extract administered 3 days prior and concurrently with gentamicin for 5 days. Blood urea, serum creatinine, uric acid and blood urea nitrogen analyses and microscopic examination of kidney were performed. Results: Gentamicin treatment caused nephrotoxicity as evidenced by marked elevation in serum urea, serum uric acid, serum creatinine and blood urea nitrogen $(107.5 \pm 16.92 \mathrm{mg} / \mathrm{dl}, 0.8 \pm 0.09 \mathrm{mg} / \mathrm{dl}$, $3.05 \pm 0.29 \mathrm{mg} / \mathrm{dl}, 47.8 \pm 9.07 \mathrm{mg} / \mathrm{dl}$ ) respectively when compared to the saline treated groups. Co-administration of Pimpinella anisum extract with gentamicin decreased the rise in these parameters in a dose dependent manner. Histopathological analysis revealed epithelial loss with intense granular degeneration in gentamicin treated rats, whereas aqueous extract of Pimpinella anisum mitigated the severity of gentamicin-induced renal damage. Conclusion: To conclude, our data suggest that aqueous extract of Pimpinella anisum exhibits renoprotective effect in gentamicin induced renal damage and further studies on its mechanism of action are warranted.
\end{abstract}

Key words: Aniseed, Gentamicin, Nephroprotective, Pimpinella anisum, Drug induced nephrotoxicity.

\section{INTRODUCTION}

Recognition of drug-induced nephrotoxicity as a significant contributor to kidney disease including acute kidney injury (AKI) and chronic kidney disease (CKD) has gained increasing momentum in recent times. Nephrotoxicity constitute a whole gamut of disorders reflecting damage to different nephron segments as a consequence of individual drug mechanisms. Consequences of drug toxicity might include both glomerular and tubular injuries leading to acute or chronic functional changes. ${ }^{1}$ The frequency of druginduced nephrotoxicity is approximately $14-26 \%$ in adult populations as detailed in previous prospective cohort studies. ${ }^{2}$ Aminoglycosides, a commonly used group of antibiotics top the causality chart in drug induced nephrotoxicity.

Aminoglycosides constitute an important part of our arsenal against many life threatening infections especially against gram negative bacterial infections. ${ }^{3,4}$ They have survived against all odds despite the introduction of highly potent, wide spectrum antibiotics because of certain properties such as rapid concentration dependent bactericidal effects, clinical effectiveness, a low rate of true resistance, synergism with other beta lactam antibiotics and low cost of therapy. ${ }^{5,6}$ However, nephrotoxicity induced by them continue to be a challenge as it results in kidney damage by a direct dose dependent mechanism. ${ }^{7,8}$ Gentamicin induced acute renal failure has proved to be an excellent working animal model for exploring the pathogenesis of drug induced acute renal failure and has resulted in an impetus to develop therapeutic approaches to minimize or prevent its harmful effects in humans. ${ }^{9}$

Renal toxicity caused by gentamicin is an elaborate phenomenon, the key features of which include an increase in plasma creatinine and urea levels with severe proximal renal tubular necrosis, with progressive deterioration and renal failure. ${ }^{10,11}$ Generation of reactive oxygen species (ROS) in the kidney have been implicated as the culprits for nephrotoxicity induced by aminoglycosides. ${ }^{11,12}$ The cellular antioxidant status plays an important role in determining the susceptibility to oxidative damage which might alter in response to oxidative stress. ${ }^{13}$ Several studies have claimed antioxidant property of drugs as crucial for their nephroprotective effects in gentamicin induced renal damage. . $^{14,15,16,17}$

Cite this article: Aiswarya N, Rashmi RR, Preethi JS, Chandran V, Teerthanath S, Sunil PB, Rakesh KB. Nephroprotective Effect of Aqueous Extract of Pimpinella anisum in Gentamicin Induced Nephrotoxicity in Wistar Rats. Pharmacog J. 2018;10(3):403-407. 
Pimpinella anisum L. (anise, aniseed), a plant belonging to the umbelliferae family, is an age old medicinal plant. ${ }^{18}$ Aniseed, a native of the Eastern Mediterranean region, is grown to a small extent in India as a culinary herb. ${ }^{19}$ They are also used as an important raw material for pharmaceutics, perfumery, food and cosmetic industries. ${ }^{20}$ It has been reported that essential oil and extracts of Pimpinella anisum have a wide range of biological activities. ${ }^{21}$ In folk medicine, pimpinella species have been used as appetizing, hypnotic, expectorant, hepatoprotective, carminative, aromatic, disinfectant, and galactagogue. ${ }^{18,22}$ Various other pharmacological properties attributed to this plant include antimicrobial, antifungal, antiviral, antioxidant, muscle relaxant, anticonvulsant, hypoglycemic, hypolipedaemic as well as different effects on gastrointestinal system. ${ }^{18}$ In recent years much attention has been devoted to natural antioxidants and their association with health benefits. Plants are a large source of new bioactive molecules with therapeutic potentials. ${ }^{23}$ Studies have shown that many dietary polyphenolic constituents derived from plants are more effective antioxidants in vitro than vitamins $\mathrm{E}$ or $\mathrm{C}$, and thus might contribute significantly to the protective effects in vivo. ${ }^{24}$ Aniseed is shown to have great health benefits due to the presence of considerable amounts of phenolic compounds that possess varying degrees of antioxidant activity. ${ }^{25}$ However literature research revealed that the nephroprotective activity of Pimpinella anisum seeds has not been established and its probable role has only been postulated with no positive evidence. Hence with this background we decided to explore the nephroprotective role of Pimpinella anisum in a murine model of gentamicin-induced renal damage.

\section{MATERIALS AND METHODS}

This study was done as per the guidelines set by the Committee for the Purpose of Control and Supervision of Experiments on Animals. The study was undertaken after obtaining the approval by the Institutional Animal Ethics Committee.

\section{Experimental Animals}

Adult Wistar albino rats of either sex, weighing 150-200g, inbred in the institutional animal house were used for the study. Animals were housed in polypropylene cages in a controlled environmental condition $\left(22 \pm 3^{\circ} \mathrm{C}\right.$, $55 \pm 5 \%$ humidity and a $12 \mathrm{~h} \mathrm{light/} \mathrm{dark} \mathrm{cycle).} \mathrm{The} \mathrm{animals} \mathrm{were} \mathrm{fed}$ with standard rodent diet and water ad libitum. They were allowed to acclimatize to these conditions for one week.

\section{Drugs}

Gentamicin sulfate injection (Piramal Health Care Ltd) was used to induce renal damage.

\section{Plant material and preparation of extracts}

Pimpinella anisum seeds were procured from the local market, authenticated by a local botanist and a voucher specimen of the plant (F.5860175) is being maintained in the herbarium of Department of Botany, St Aloysius, College,Mangalore. Theseedswerecleanedanddriedinshadeand powdered by a mechanical grinder. For the aqueous extract, the seed powder $(100 \mathrm{~g})$ was added to $1000 \mathrm{~mL}$ of hot water, boiled for $15 \mathrm{~min}$ and filtered. The filtrate was evaporated to dryness under reduced pressure to afford a viscous residue. The residue was dissolved in normal saline for oral administration. ${ }^{26}$

\section{Experimental procedure}

After acclimatization, the animals were divided randomly into five groups of 6 animals each and placed in separate cages. The test drug, the aqueous extract of Pimpinella anisum seeds and gentamicin were administered for a total duration of 8 days. The test drug was started 3 days prior to the commencement of the study. The animals were grouped accordingly as follows: Group one served as control group and received normal saline $(1 \mathrm{ml} / \mathrm{kg}$ intraperitoneal) throughout the course of the experiment. Group two received daily intraperitoneal injections of gentamicin $(80 \mathrm{mg} / \mathrm{kg}) .{ }^{14}$ Group three, four and five received the test drug, aqueous extract of Pimpinella anisum orally at 1,2 and $4 \mathrm{~g} / \mathrm{kg}$ respectively. ${ }^{26}$ Animals of group three, four and five were administered $80 \mathrm{mg} / \mathrm{kg}$ of gentamicin intraperitoneal along with test drug for 8 days.

\section{Sample collection and biochemical assays}

Twenty-four hour after the last injection the rats were anesthetized with ketamine $(60 \mathrm{mg} / \mathrm{kg})$ and xylazine $(5 \mathrm{mg} / \mathrm{kg})$ intraperitoneally ${ }^{27}$ and blood samples were collected by cardiac puncture. The serum was rapidly separated and processed for determination of serum creatinine, serum urea, serum uric acid and blood urea nitrogen (BUN) as an indicator of kidney damage, using commercially available kits from Aspen Diagnostics Private Ltd (Liquid stable biochemistry kits). The animals were sacrificed and both kidneys were isolated. The kidneys from all the groups were weighed and processed for histopathological examination.

\section{Histopathological examination}

The kidneys fixed in 10\% neutral buffered formalin were processed and embedded in paraffin wax and sections were taken using a microtome. Sections (5 microns) were then stained with haematoxylin and eosin and examined under light microscope. They were evaluated and assigned scores as follows: ${ }^{14}$

Score $0=$ Normal

Score 1 = Areas of focal granulovacuolar epithelial cell degeneration and granular debris in tubular lumens with or without evidence of tubular epithelial cell desquamation of small foci ( $<1 \%$ of total tubule population)

Score 2 = Tubular epithelial necrosis and desquamation easily seen but involving less than half of cortical tubules

Score 3 = More than half of proximal tubules showing desquamation of necrosis but involved tubules easily found

Score 4 = Complete or almost complete tubular necrosis

\section{Statistical analysis}

Data were expressed as mean \pm standard error of mean (SEM). Statistical evaluation was done using SPSS (version 20). Kruskal-Wallis test was performed to find whether or not values of different groups differ significantly. To test intergroup significant difference, Mann-Whitney test was performed. A value of $p<0.05$ was considered statistically significant.

\section{RESULTS}

\section{Effect on biochemical parameters}

In the present study, gentamicin $(80 \mathrm{mg} / \mathrm{kg})$ when injected for eight consecutive days caused marked nephrotoxicity as is evident from Table 1, showing significant $(p<0.05)$ increase in serum urea $(107.5 \pm 16.92 \mathrm{mg} / \mathrm{dl})$, serum creatinine $(0.8 \pm 0.09 \mathrm{mg} / \mathrm{dl})$, serum uric acid $(3.05 \pm 0.29 \mathrm{mg} / \mathrm{dl})$ and blood urea nitrogen $(47.8 \pm 9.07 \mathrm{mg} / \mathrm{dl})$ as compared to normal control animals. The test drug, aqueous extract of Pimpinella anisum depicted protective effects at doses 1,2 and $4 \mathrm{~g} / \mathrm{kg}$ body weight by reducing the levels of serum urea, creatinine, uric acid and blood urea nitrogen as compared to gentamicin treated group but not in a dose dependent manner. There was a significant nephroprotective effect at doses 1 and $2 \mathrm{~g} / \mathrm{kg}$ body weight of the test drug as evidenced by a significant decrease in serum urea, creatinine, uric acid and blood urea nitrogen $(p<0.05)$ as compared to gentamicin treated group.

\section{Histopathological changes}

The histological changes in the kidney of all the groups were graded and the results are expressed in Table 2. It was noted that the microscopic study of the kidney sections of the rats which were treated with normal 
Table 1: Effects of gentamicin and aqueous extract of Pimpinella anisum on serum urea, creatinine, uric acid and blood urea nitrogen (BUN).

\begin{tabular}{|c|c|c|c|c|c|}
\hline \multirow[t]{2}{*}{ Group } & \multirow[t]{2}{*}{ Treatment } & \multicolumn{4}{|c|}{ Parameters } \\
\hline & & Urea (mg/dl) & Creatinine (mg/dl) & Uric acid (mg/dl) & BUN (mg/dl) \\
\hline 1 & Normal control ( $1 \mathrm{ml} / \mathrm{kg}$, i.p) & $53.8 \pm 18.6$ & $0.5 \pm 0.06$ & $1.7 \pm 0.34$ & $25.09 \pm 8.69$ \\
\hline 2 & Gentamicin (80mg/kg, i.p) & $107.5 \pm 16.92^{*}$ & $0.8 \pm 0.09^{*}$ & $3.05 \pm 0.29^{*}$ & $47.8 \pm 9.07^{*}$ \\
\hline 3 & Pimpinella anisum $(1 \mathrm{~g} / \mathrm{kg}$, oral $)+$ gentamicin $(80 \mathrm{mg} / \mathrm{kg}$, i.p) & $55 \pm 8.68^{* *}$ & $0.6 \pm 0.07^{* *}$ & $1.96 \pm 0.15^{* *}$ & $25.4 \pm 3.88^{* *}$ \\
\hline 4 & Pimpinella anisum $(2 \mathrm{~g} / \mathrm{kg}$, oral $)+$ gentamicin $(80 \mathrm{mg} / \mathrm{kg}$, i.p) & $29.3 \pm 2.38^{* *}$ & $0.58 \pm 0.04^{* *}$ & $2.4 \pm 0.61^{* *}$ & $13.4 \pm 1.04^{* *}$ \\
\hline 5 & Pimpinella anisum ( $4 \mathrm{~g} / \mathrm{kg}$, oral) + gentamicin $(80 \mathrm{mg} / \mathrm{kg}$, i.p) & $93.16 \pm 21.5$ & $0.7 \pm 0.07$ & $2.6 \pm 0.24$ & $43.5 \pm 9.78$ \\
\hline
\end{tabular}

Values are expressed as mean \pm SEM.

${ }^{*} \mathrm{p}<0.05$ when compared to normal control group.

${ }^{* *} \mathrm{p}<0.05$ when compared to gentamicin treated group.

Table 2: Semi quantitative comparison and scores of the histopathological renal damage of rats of different treatment groups.

\begin{tabular}{|c|c|c|c|c|c|}
\hline Histopathological feature & $\begin{array}{l}\text { Normal } \\
\text { control }\end{array}$ & Gentamicin & $\begin{array}{c}\text { Pimpinella } \\
\text { anisum }(1 \mathrm{~g} / \mathrm{kg})\end{array}$ & $\begin{array}{c}\text { Pimpinella } \\
\text { anisum }(2 \mathrm{~g} / \mathrm{kg})\end{array}$ & $\begin{array}{c}\text { Pimpinella } \\
\text { anisum }(4 \mathrm{~g} / \mathrm{kg})\end{array}$ \\
\hline Glomerular infiltration & - & +++ & ++ & + & - \\
\hline Interstitial congestion & - & +++ & ++ & ++ & - \\
\hline Interstitial infiltration & - & +++ & ++ & + & Sparse, scattered \\
\hline Tubular regeneration & - & - & - & - & +++ \\
\hline Average score & 0 & 3 & 2 & 1.7 & 0.6 \\
\hline
\end{tabular}

saline appeared histologically normal with the score of 0 . The kidney sections of the gentamicin treated group showed extensive tubular necrosis involving most of the renal cortex with an average score of 3 . The observed changes included dilated tubules with denuded epithelium, intracytoplasmic vacuolation, blebs, interstitial and glomerular congestion, stromal inflammation and granular casts as depicted in Figure 1. The histomorphology of the kidney sections in rats treated with aqueous extract of Pimpinella anisum at doses 1 and $2 \mathrm{~g} / \mathrm{kg}$ showed moderate tubular epithelial degeneration with dilated tubules and luminal granular necrotic casts with an average score of 2 and 1.7 respectively, as depicted in Figure 2. The dose at $4 \mathrm{~g} / \mathrm{kg}$ of Pimpinella anisum showed significant histological changes with presence of regenerating tubules illustrating protection against the gentamicin induced damage with an average score of 0.6 , as in Figure 3.

\section{DISCUSSION}

Drug-induced nephrotoxicity is increasingly recognized as a harbinger to kidney disease including acute kidney injury and chronic kidney disease. The renal toxicity of aminoglycosides, especially gentamicin
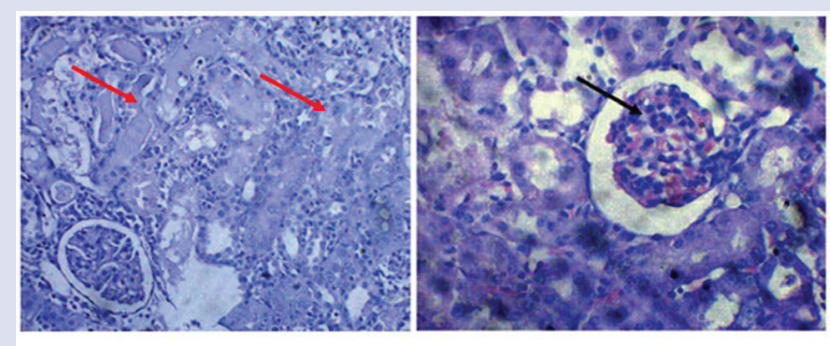

A

B

Figure 1: Photomicrograph of kidney sections of gentamicin treated group: showing extensive necrosis (red arrow), glomerular congestion (black arrow), interstitial congestion and inflammatory cell infiltration (40 X, H \&E).
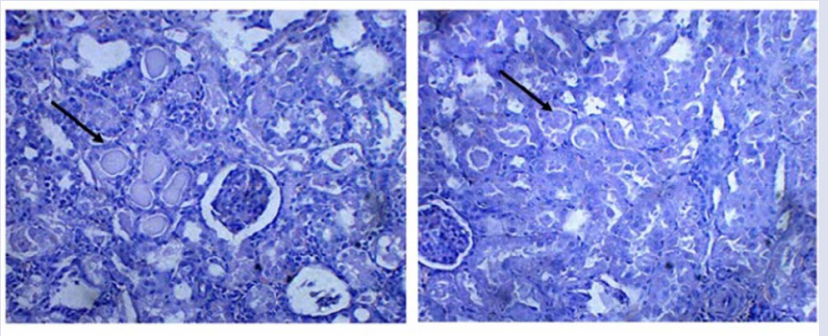

A

B

Figure 2: Photomicrograph of kidney sections treated with aqueous extract of Pimpinella anisum at doses 1 and $2 \mathrm{~g} / \mathrm{kg}$ : showing granular casts (black arrow) and degenerated tubular epithelium (40X, H \&E).

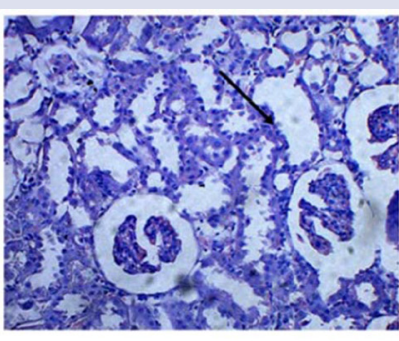

A

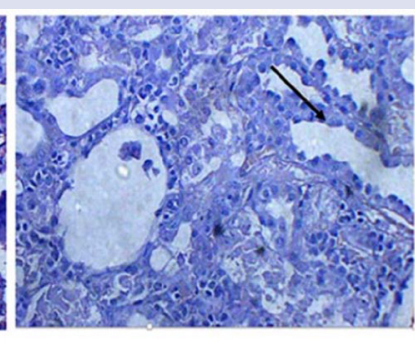

B
Figure 3: Photomicrograph of kidney sections treated with aqueous extract of Pimpinella anisum at dose $4 \mathrm{~g} / \mathrm{kg}$ : showing dilated tubules with flattened epithelium in the regenerative phase after tubular injury (black arrow), shedding of necrotic cells (40X, H \&E).

is now a well-established fact. ${ }^{4}$ Agents ameliorating aminoglycoside nephrotoxicity would offer a distinct clinical advantage in therapeutics employing gentamicin. In view of this the present study was aimed to evaluate the nephroprotective action of the aqueous extract of Pimpinella anisum in gentamicin induced acute renal failure in a murine model. 
Results of this study confirmed that gentamicin at a dose of $80 \mathrm{mg} / \mathrm{kg}$ produces significant nephrotoxicity as evidenced by histological changes of the kidneys that include tubular necrosis, dilatation of tubules, degeneration of tubular epithelial cells with casts in the tubular lumen, cell infiltration in interstitium, marked congestion of the glomeruli and extensive necrosis with alteration of corresponding biochemical parameters as shown by increase in serum urea, creatinine, uric acid, blood urea nitrogen. The present histological and biochemical findings in gentamicin treated group correlate with previous reports. ${ }^{11-17}$

Pretreatment with aqueous extract of Pimpinella anisum provided marked nephroprotection against gentamicin induced renal damage in rats as evidenced by significant reduction in biochemical parameters. This is supported by histopathological evaluation; concurrent administration of Pimpinella anisum appeared to mitigate the severity of the gentamicin-induced renal necrosis, resulting in the preservation of the tubular histology by significantly reducing the scores of histopathological damages compared to gentamicin treated group. The signs of regeneration of tubules were also seen, which was prominent at highest dose. Restoration of the structure of glomerulus and renal tubules in Pimpinella anisum pretreated group provides a direct evidence for nephroprotective activity of this extract.

Recent studies have demonstrated an accumulating body of evidence to support the pre-concept of participation of reactive oxygen metabolites including free radicals in renal tissue injury. A clear relationship between oxidative stress and nephrotoxicity has been hypothesized and proved in many experimental animal models. ${ }^{28,29}$ Gentamicin enhances the generation of hydrogen peroxide and oxygen free radicals. Reactive oxygen species (ROS) may produce cellular injury and necrosis via, several mechanisms including peroxidation of membrane lipids, protein denaturation and DNA damage..$^{28}$ It has also been considered that gentamicin alters the basolateral membrane and mitochondria enhancing production of free radicals and lipid peroxidation of renal cortex. ${ }^{30}$ Gentamicin is wellknown to reduce the activities of catalase, glutathione peroxidase and the levels of reduced glutathione. Consumption of foods rich in polyphenolic compounds which delay or prevent the oxidation of cellular oxidizable substrates by direct radical scavenging action or indirect antioxidant action, such as inhibition of ROS producing enzymes (xanthine oxidase, lipoxygenase etc.) provides a logical strategy to minimize these health risks and balance these ROS. ${ }^{31}$ Moreover, this has been adequately tried and tested in previous studies which have shown considerable renoprotection by pretreating rats with hydroxyl radical scavengers. ${ }^{13}$

Several experimental studies have shown antioxidant potential of Pimpinella anisum. ${ }^{19,31,32}$ Phytochemical screening of aniseed has revealed polyphenolic compounds like flavonoids, tannins, and phenolic acids as major components. These are very vital for the free-radical scavenging and antioxidant activities of plants as they act as hydrogen donors and thus neutralize the free-radicals ${ }^{32}$ as assessed by DPPH and ABTS radical scavenging activity assays. This radical scavenging potential of aniseed extract can also be supported by significantly decreased lipid peroxidation in the in vitro models. ${ }^{19}$ Moreover, its antioxidant activity has also been partially held responsible for its preventive and therapeutic effects on acute hepatic injury in rats. ${ }^{33}$

Because of the above properties aniseed can protect biomolecules like proteins, nucleic acids, poly unsaturated fatty acids in membranes and prevent most of the biological molecules from oxidation, thus decreasing the rate of the lipid peroxidation. ${ }^{19}$ Further studies are required to explore and associate the antioxidant effect to nephroprotection afforded by Pimpinella anisum which might help better characterize its mechanism in attenuating gentamicin induced renal damage.

\section{CONCLUSION}

To conclude, this study provides scientific evidence of the nephroprotective effects of orally administered aqueous extract of Pimpinella anisum in gentamicin induced renal damage.

\section{ACKNOWLEDGEMENT}

The authors acknowledge with gratitude the funds received for the project from the ICMR as Short Term Student (STS) grant. The authors also acknowledge the assistance of Dr K V Nagalakshamma, Head of the Department of Botany, St Aloysius College, in authentication of the plant seeds.

\section{CONFLICT OF INTEREST}

The authors declare no conflict of interest.

\section{SUMMARY}

The present study provides evidence that pre-treatment and co-administration of Pimpinella anisum along with gentamicin prevents both functional and histological renal changes induced by gentamicin in rats.

\section{REFERENCES}

1. Awdishu L, Mehta RL. The $6 R$ 's of drug induced nephrotoxicity. BMC Nephrology 2017;18(1):124.

2. Hoste EA, Bagshaw SM, Bellomo R, Cely CM, Colman R, Cruz DN, et al. Epidemiology of acute kidney injury in critically ill patients: the multinational AKI-EPI study. Intensive Care Med. 2015;41(8):1411-23.

3. Swain RA, Kaplan-Machlis B. Therapeutic uses of vitamin $E$ in prevention of atherosclerosis. Altern Med Rev. 1999;4(6):414-23.

4. Mingeot-Leclercq MP, Tulkens PM. Aminoglycoside Neprotoxicity. Antimicrob Agents Chemother. 1999;43(5):1003-12.

5. Begg EJ, Barclay ML. Aminoglycosides-50 years. Br J Clin Pharmacology. 1995;39(6):597-603

6. Edson RS, Terrel CL. The Aminoglycosides. Mayo Clin Proc. 1999;74(5):519-28.

7. Khoory BJ, Fanos V, Dall AA, Cataldi L. Aminoglycosides, risk factors and neonatal kidney. Pediatr Med Chir. 1996;18(5):495-9.

8. Rougier F, Claude D, Maurin M, Maire P. Aminoglycoside Nephrotoxicity. Curr Drug Targets Infect Disord. 2004;4(2):153-62.

9. Murakami H, Yayama K, Chao J, Chao L. Atrial natriuretic peptide gene delivery attenuates gentamycin-induced nephrotoxicity in rats. Nephrol Dial Transplant.1999;14(6):1376-84.

10. Cuzzocrea S, Mazzon E, Dugo L, Serraino I, Di-Paola R, Britti D, et al. A role for superoxide in gentamicin-mediated nephropathy in rats. Eur J Pharmacology. 2002:450(1):67-76.

11. Al-Majed A, Mostafa AM, Al-Rikabi AC, Al-Shabanah O. Protective effects of oral Arabic gum administration on gentamicin nephrotoxicity in rats. Pharmacology Res. 2002;46(5):445-51.

12. Reiter RJ, Tan D, Sainz RM, Mayo JC, Lopez-Burillo S. Melatonin: reducing the toxicity and increasing the efficacy of drugs. J Pharm Pharmacology. 2002; 54(10):1299-321.

13. Halliwell B, Gutteridge JMC. Free radicals in biology and medicine. Oxford: Clarendon Press; 1999.

14. Kumar KV, Naidu MUR, Shifow AA, Ratnakar KS. Probucol protects against gentamicin-induced nephrotoxicity in rats. Indian J Pharmacol. 2000;32(2):108-113.

15. Abdel-Raheem IT, Abdhal-Ghany AA Mohamed GA. Protective effects of Quercetin against gentamicin-induced nephrotoxicity in rats. Biol. Pharm. Bull. 2009;32(1):61-7.

16. Yaman I, Balikci E. Protective effects of nigella sativa against gentamicininduced nephrotoxicity in rats. Experimental and Toxicologic Pathology. 2010;62(2):183-90.

17. Harlalka GV, Patil CR, Patil MR. Protective effects of Kalanchoe pinnata pers. (Crassulaceae) on gentamicin-induced nephrotoxicity in rats. Indian J Pharmacol. 2007;39(4):201-5

18. Saini N, Singh GK, Nagori BP. Spasmolytic potential of some medicinal plants belonging to family umbelliferae: A Review. Int. J. Res. Ayurveda Pharm. 2014;5(1):74-83

19. Shobha RI, Andallu B. Radical scavenging and antiperoxidative efficacy of aniseeds (Pimpinella anisum L.): identification of phytoceuticals. Pharmaceutical and biological evaluations. 2015;2(5):197-203. 
20. Ross IA. Medicinal plants of the world: chemical constitutes, traditional and modern medicinal uses. Totowa, New Jersey: Humana Press; 2001;2:363-74.

21. Jamshidzadeh A, Heidari R, Razmjou M, Karimi F, Moein MR, Farshad O et al. An in vivo and in vitro investigation on hepatoprotective effects of Pimpinella anisum seed essential oil and extracts against carbon tetrachloride-induced toxicity. Iran J Basic Med Sci. 2015;18(2):205-11.

22. Ozturk Y, Baser KHC, Aydin S. Hepatoprotective (antihepatotoxic) plants in Turkey. Proceedings of the $9^{\text {th }}$ symposium on plant drugs, Eskisehir. 1991.p.40-50.

23. Hashempour A, Mohammad HSZ, Yousefi S, Hashempour N. In vivo effect of Pimpinella anisum seeds essential oils on Mouse mice BAL b/c breed infected with Listeriosis disease. Sch Acad J Bioscience. 2014;2(10):700-3

24. Rice-Evan C, Miller N, Paganga G. Antioxidant properties of phenolic compounds. Trends in Plant Science. 1997;2(4):152-9.

25. Shobha RI, Rajeshwari CU, Andallu B. Phytoconstituents and lipoxidase and xanthine oxidase inhibitory effects of methanolic extract of aniseeds (Pimpinella anisum L.). Int J Pure App. Bioscience. 2014;2(2):81-5.

26. Hosseinzadeh H, Tafaghodi M, Abedzadeh S, Taghiabadi E. Effect of Aqueous and Ethanolic Extracts of Pimpinella anisum L. Seeds on Milk Production in Rats. J Acupuncture Meridian Stud. 2014;7(4):211-16.

27. Gowda KPS, Swamy BMV. Histopathological and nephroprotective study of aqueous stem bark extract of Ficus racemosa in drug induced nephrotoxic rats.
IOSR Journal of Pharmacy. 2012;2(2):265-70

28. Arivazhagan SJJ, Vimaastalin R. Nephroprotective activity of Aristo lochia Indica leaf extract against gentamicin induced renal dysfunction. International Journal of Research in Biochemistry and Biophysics. 2014;4(2):13-8.

29. Shifow AA, Kumar KV, Naidu MUR, Ratnakar KS. Melatonin, a pineal hormone with antioxidant property, protects against gentamicin-induced nephrotoxicity in rats. Nephron. 2000;85(2):167-74.

30. Shimmi SC, Jahan N, Baqi N, Rahman Z. Histological evidence of nephroprotective effect of Ashwagandha (Withania somnifera) root extract against gentamicin induced nephrotoxicity in rats. J Enam Med Col. 2014;4(1):26-30.

31. Shobha RI, Rajeshwari CU, Andallu B. Phytoconstituents and lipoxidase and xanthine oxidase inhibitory effects of methanolic extract of aniseeds (Pimpinella anisum L.). Int J Pure App Bioscience. 2014;2(2):81-5.

32. Christova-Bagdassarian VL, Bagdassarian KS, Atanassova MS, Ahmad MA Comparative analysis of Total Phenolic and Total Flavonoid contents, Rutin, Tannins and Antioxidant capacity in Apiaceae and Lamiaceae families. Indian Horticulture Journal. 2014;4(3/4):131-40.

33. Cengiza N, Ozbekb H, Him A. Hepatoprotective effects of Pimpinella anisum seed extract in rats. Pharmacology online. 2008;3:870-4.

Cite this article: Aiswarya N, Rashmi RR, Preethi JS, Chandran V, Teerthanath S, Sunil PB, Rakesh KB. Nephroprotective Effect of Aqueous Extract of Pimpinella anisum in Gentamicin Induced Nephrotoxicity in Wistar Rats. Pharmacog J. 2018;10(3):403-407. 